\title{
溶融亚鉛メッキ鋼材と CFRP と A STUDY OF ADHESION STRENGTH の接着強度に関する考察 FOR JOINT OF GALVANIZED STEEL AND CFRP
}

$\begin{array}{ll}\text { 松井孝洋——1 } & \text { 山本展久— }-11 \\ \text { 服部明生— }-2 & \text { 松本幸大 }-33\end{array}$

キーワード :

接着強度, 亜鉛メッキ, 炭素繊維強化樹脂

Keywords:

Adhesion strength, Galvanized steel, Carbon fiber reinforced polymer

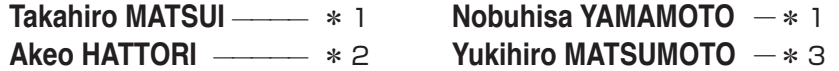

Recently, it is highly important issue that the aging degradation of the structural members caused by corrosion and/or fatigue cracks. Therefore, repair and reinforcement method by using CFRP have been developed in many years. However, in the case of galvanized steel members, it is not recommended that removing the galvanizations to ensure the adhesion strength of the reinforcement material because of occurrence other corrosions. Based on these, the adhesion strength of galvanized steel and CFRP is investigated without removing the galvanizations through tensile shear test in this paper.
1. はじめに

高度成長期から半世紀以上を過ぎた我国の構造物において, 多数 の経年劣化が顕在化してきており,喫緊の社会的課題となっている。 鋼構造分野においては, 主に腐食や疲労亀裂発生が劣化の原因とし て挙げられ，近年，その調查事例や補修・補強に関する研究が報告 されている ${ }^{1-5)}$ 。補修・補強については，軽量・高強度で耐食性に 優れる炭素繊維強化樹脂（CFRP）の接着工法による断面性能の回復 技術が多く開発されており ${ }^{4,5)}$, 構造物の重量増加を最小限に抑え る劣化対策技術として有用である。ところで，鋼構造の腐食対策と しては亜鉛メッキが挙げられるが，長期の腐食対策として採用され た溶融亜鉛メッキ鋼材の場合においても深刻な腐食の発生が指摘さ れている ${ }^{3)}$ 。こうした，溶融亜鉛メッキ鋼材の腐食に対して，CFRP 接着工法により対策を行う場合, CFRP の定着部分においては鋼材表 面のメッキ層を除去して接着することが接着強度の確保に対して有 効であるとの指摘がなされている ${ }^{5)}$ 。一方，メッキ層を除去するこ とは，構造材である鋼材の断面をも減少させることに繋がること， また，本来防食材として適用されているメッキ層を除去してしまう ことは, 接着施工時の天候や環境, また, 接着層内の空隙等により, 新たな腐食を発生させてしまう原因となることが考えられる。すな わち, 部材の構造性能を改善させることと, 残存する構造材への影 響を最小限にすること，並びに防食対策の維持とを両立することが できる接着補強が期待される。

以上の観点から，本報告では，溶融亜鉛メッキ表面に対してメッ キ表面を除去することなくCFRP を接着補強することを想定した, 技 術開発の基礎データ収集を目的として，溶融亜鉛メッキ表面におけ る表面処理と接着強度との関係，また，溶融亜鈆メッキ表面に CFRP を接着した後, 紫外線および温度履歴を対象とした促進曝露試験を 通した接着強度の変化を報告する。なお，犠牲防食作用により鋼材
の腐食を防止する亜鉛メッキでは, メッキ層を除去する方が長期の 接着強度維持の可能性があるが, CFRP 接着範囲のみに限定してケレ ンを行うことは困難であり，境界付近を含めはみ出し部分の耐久性 に課題が残る。ことから，接着強度に遜色がないメッキ面は残すこ ととした。

\section{2.引張せん断接着強さ}

\section{1 試験体と試験方法}

本章では，溶融亜鉛メッキ（HDZ45）された鋼材同士の接着強度に ついて分析する。接着強度は JIS K 6850（接着剤一剛性被着材の引 張せん断接着強さ試験方法）に準拠し行った。試験体寸法を図 1 に 示す。試験変数は, 表 1 に示すように CFRP の種類, 表面の目粗し方 法，接着剤の種類とした。CFRP に関して，現場含浸させて CFRPを 形成する CF シートと, 工場で引抜成形する CFRP 帯板の 2 種類とし た。表面処理に関しては図 2 に示すように，亜鉛メッキ層を除去す る方法としない方法を採用した。図 2 の表記方法は表 1 の表面処理 方法に記載する記号に対応しており，施工時は，目視で研磨後の表 面光沢を確認しながら手作業で万遍なく処理した。接着剤に関して は，コンクリート補強用で実績があり，CF シートの含浸樹脂を兼衩

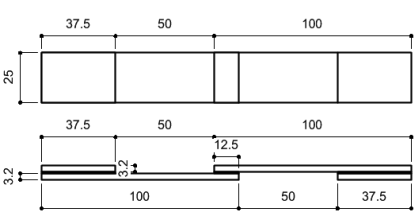

（a）引張せん断接着強さ試験体

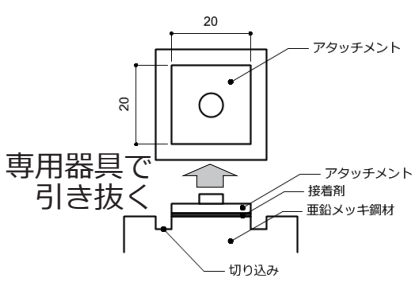

（b）建研式接着強度試験体

\section{図 1 試験体の概要}

\footnotetext{
”1 東レ(株) コンポジット技術第 1 部 コンポジット技術部第 1 課

（干 455-8502 愛知県名古屋市港区大江町 9-1）

"2 東レ建設(侏) 技術部 博士 (工学)

3 豊橋技術科学大学 建築・都市システム学系 准教授・博士 (工学)
1st Advanced Composites Technical Section, 1st Advanced Composites Technical Dept., Toray Industries, Inc.
Technical Dept., Toray Construction Co., Ltd., Dr. Eng. Technology, Dr. Eng.

3 Assoc. Prof., Dept. of Architecture and Civil Engineering, Toyohashi Univ. of
} 
表 1 接着性試験の試験変数

\begin{tabular}{|c|c|c|c|c|}
\hline 試験体名 & CFRP の種類 & $\begin{array}{c}\text { 表面処理 } \\
\text { 方法 }\end{array}$ & $\begin{array}{c}\text { メッキ層の } \\
\text { 状況 }\end{array}$ & 接着剂 \\
\hline $\mathrm{G}-\mathrm{N}-\mathrm{E} 0$ & \multirow{5}{*}{ CF シート } & なし & & \multirow{5}{*}{$\begin{array}{c}\text { E2500 } \\
\text { (コニシ製) }\end{array}$} \\
\hline $\mathrm{G}-\mathrm{BL}-\mathrm{E} 0$ & & $\mathrm{BL}$ & 一部除去 & \\
\hline G-WC-E0 & & WC & 目粗し程度 & \\
\hline G-SP-E0 & & SP & 一部除去 & \\
\hline G-DG-E0 & & $\mathrm{DG}$ & 完全除去 & \\
\hline $\mathrm{G}-\mathrm{N}-\mathrm{E} 8$ & \multirow{5}{*}{ CFRP 帯板 } & なし & & \multirow{5}{*}{$\begin{array}{c}\mathrm{E} 258 \\
\text { (コニシ製) }\end{array}$} \\
\hline G-BL-E8 & & $\mathrm{BL}$ & 一部除去 & \\
\hline G-WC-E8 & & WC & 目粗し程度 & \\
\hline G-SP-E8 & & SP & 一部除去 & \\
\hline G-DG-E8 & & DG & 完全除去 & \\
\hline
\end{tabular}

\begin{tabular}{|c|c|c|}
\hline 名称 & $\begin{array}{l}\text { 表記 } \\
\text { 方法 }\end{array}$ & 表面処理の内容 \\
\hline \multirow[t]{2}{*}{$\begin{array}{c}\text { ロータリー式 } \\
\text { ブラスター }\end{array}$} & BL & \\
\hline & & $\begin{array}{l}\text { ワイヤーブラシを高速縦回転させる表面処理 } \\
\text { メッキ層は除去されない }\end{array}$ \\
\hline \multirow{2}{*}{$\begin{array}{c}\text { ワイヤー } \\
\text { カップブラシ }\end{array}$} & WC & \\
\hline & & $\begin{array}{l}\text { ワイヤーブラシ（線径 0.35）を横速縦回転させ } \\
\text { る表面処理 } \\
\text { メッキ層は除去されない } \\
\end{array}$ \\
\hline $\begin{array}{l}\text { サンド } \\
\text { ペーパー }\end{array}$ & SP & $\begin{array}{l}40 \text { 番手のサンドペーパーを用いた, 表面処理 } \\
\text { メッキ層が除去されるまでは処理は行わない }\end{array}$ \\
\hline $\begin{array}{c}\text { ディスク } \\
\text { グラインダー }\end{array}$ & DG & $\begin{array}{l}\text { 粒度 } 36 \text { の研削砥石を用いたグラインダー処理 } \\
\text { メッキは完全に除去される }\end{array}$ \\
\hline
\end{tabular}

図 2 表面処理方法の一覧

る接着剂である E2500（E0）と CFRP 帯板の鋼材補強用として広く用 いられているE258（E8）を採用した。接着剤は何れも2 液系常温硬 化型エポキシ樹脂接着剤である。

\section{2 引張せん断接着強度と建研式接着強度}

試験結果を図 3 に示す。試験体数は JIS K 6850 において定められ
ている 5 体（最低数）とし，変動係数は引張せん断接着強度で最大 $26 \%$, 建研式接着試験で最大 $40 \%$ でった。試験は, 接着剤の硬化に 配慮して, 施工後 4 日間以上経過後とし室内養生を行った。縦軸に 引張せん断接着強度 $\tau$, 横軸に建研式接着強度 $\sigma_{\mathrm{z}}$ とし, 表面処理方法 の同じ試験を対応させるため, 同条件の試験体において $て \sigma_{\mathrm{z}}$ が平均 值で交差させ, 各データの \pm 1.5 倍の標準偏差の範囲で表した。各 接着強度を平均值から標準偏差を 1.5 倍した值で除して評価すると, 表面処理を施した試験体に関して，含浸接着樹脂で $\tau \geqq 11 \mathrm{MPa}, \sigma_{\mathrm{z}} \geqq$ $4 \mathrm{MPa}, C F R P$ 帯板用接着剂で $\tau \geqq 13 \mathrm{MPa} ， \sigma_{\mathrm{z}} \geqq 5 \mathrm{MPa}$ となった。一方, 表 面処理のない試験体では, 含浸接着樹脂は上述範囲を下回ったが, CFRP 帯板用接着剂は上述範囲内であった。また, 含浸接着樹脂は相 対的にCFRP 帯板用接着剤に比べて接着強度が劣る傾向にある。つま り，使用する接着剤による接着特性の違いが出たものと考察する。 以上から, 何れの接着剤を選択しても, 表面処理を施せば引張せん 断接着強度は $11 \mathrm{MPa}$ を確保でき, 且つ, その時の建研式接着強度は 4MPa 以上になることを実験にて確認できた。

\section{3 算術平均粗さ Ra と接着強度}

引張せん断接着強さ試験後の試験片の写真を図 4 に, 表面処理後 の算術平均粗さRa と引張せん断接着強度の関係を図 5 に示す。算術 平均粗さはJIS B 0031 に示されており, 測定範囲（本研究では任意 位置の $10 \mathrm{~mm}$ の直線部) における粗さ曲線と粗さ曲線の平均線とで囲 まれた面積を長さで除した值である。ディスクグラインダーで表面 処理した試験体では Ra が高くなっているが，当該 Ra の範囲におい ては表面粗さが引張せん断接着強度向上に繋がる要因とはならなか った。また, DG以外の亜鉛メッキを除去しない表面処理法は, 試験 後も覀鉛メッキが剥離することなく, 健全状態のままであった。試 験体の破壊性状は, 含浸接着樹脂では樹脂の界面剥離, CFRP 帯板用 接着剂では接着剂の凝集破壊が多い結果となった。界面剥離は接着 剂の性能を十分発揮できた破壊性状とは考えにくい。これより含浸 接着樹脂は物理的・化学的な表面処理によって更に接着強度が上昇 する可能性がある。一方, CFRP 帯板用接着剤は材料強度に達してい ると言え, 本工法の最大接着強度であると考えられる。

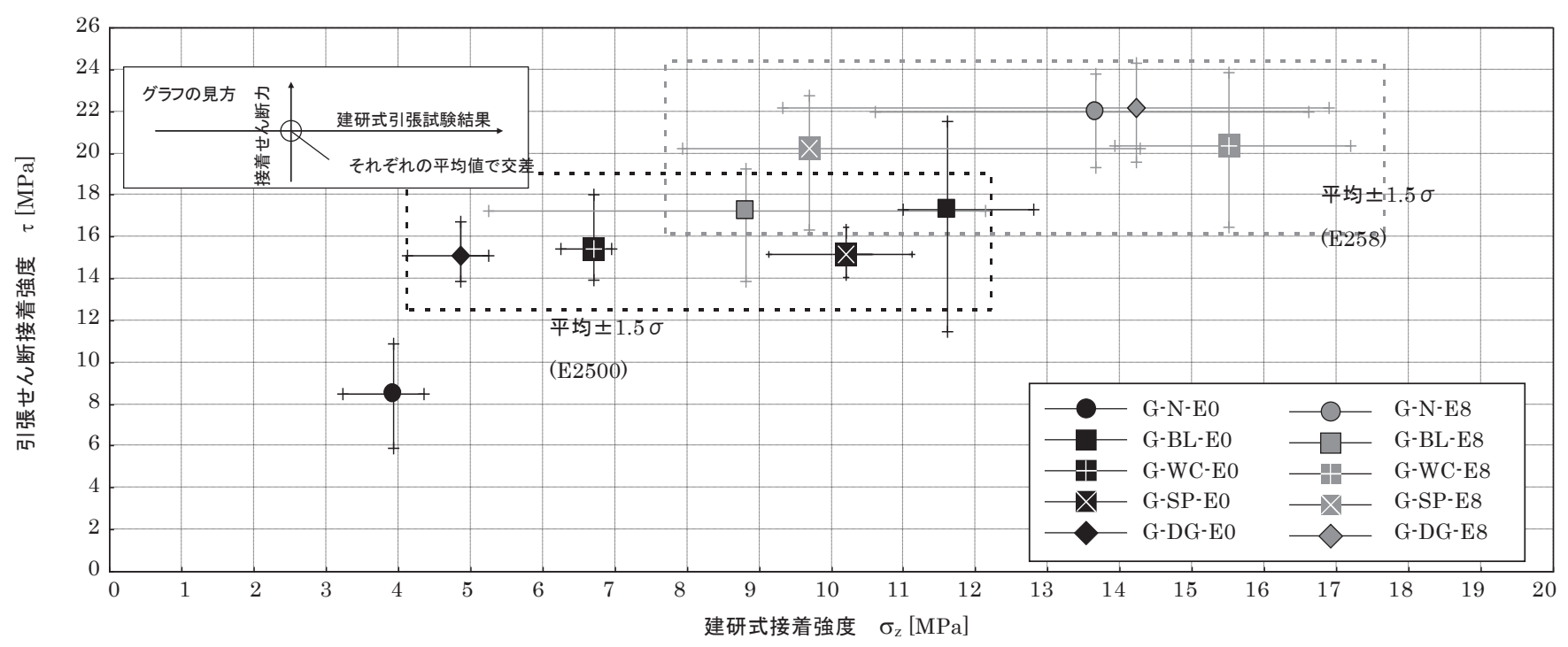

図 3 引張せん断接着試験と建研式接着試験結果 


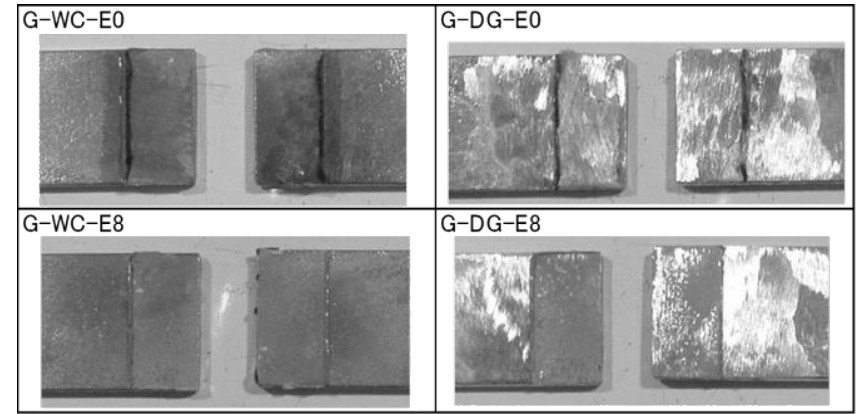

図 4 破断後の状況

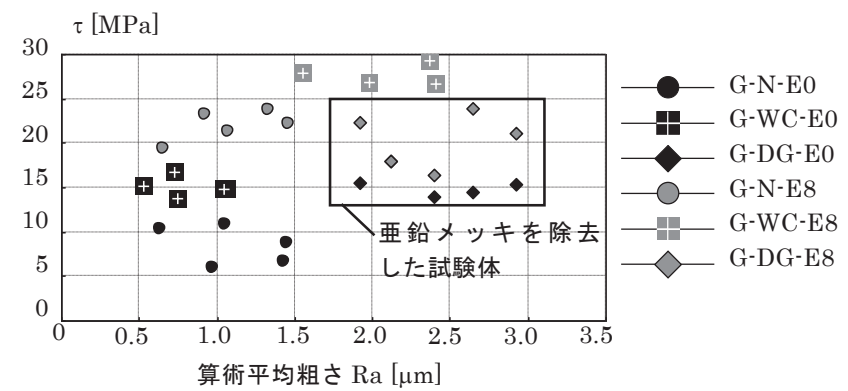

図 5 表面粗さと引張せん断接着強度の関係

\section{3. 耐候性試験と引張せん断接着強さ}

\section{1 試験体と試験方法}

本章では, 紫外線が鋼材と CFRP との接着強度に及ぼす影響につい

て分析する。鋼材側の表面処理は前章の結果より,メッキが完全除 去されず，同時に表面に適度な目粗し面を形成でき，接着強度も高 いワイヤーカップブラシ（WC）を採用した。試験体寸法は, 図 1 に 示した引張せん断接着強さ試験体と同じであり, 試験体帯板の片方 をCFRP とした。すなわち, 表 1 に示す G-WC-E0 と G-WC-E8 に対応す る試験片について, 亜鉛メッキ鋼材と CFRP 材との耐候性試験を実施 した。表 2 にCFRP 材の概要を示す。なお，CF シートは，CFRP 帯板 と同程度の引張剛性となる $\mathrm{CF}$ シート枚数を積層した。試験変数を表 3 に示す。鋼材は, 亜鉛メッキ処理した新品と, 経年により撤去し た鋼構造物から切り出された亜鉛メッキ部材の経年劣化品を用いた。 耐候性試験は，JIS A 1415 に記載するサンシャインカーボンアーク ランプによる曝露試験方法（試験条件：ブラックパネル温度 $63^{\circ} \mathrm{C}$, 相対湿度 50\%（照射安定時），スプレーサイクル 18 分 / 102 分）で 実施し, 接着而久性の評価法は JIS K 6850 に準拠した面内方向の引 張せん断接着強度の劣化度にて確認した。評価として0（耐候性試 験前)，500，1000 及び 2000 時間の照射時間毎に引張せん断接着強 度を確認した。繊維強化樹脂・接着剂は紫外線により樹脂の劣化が 生じ，材料物性值の劣化が懸念されることから，本試験法を採用し ている。なお，採用したサンシャインカーボンアークランプは， 255W/ $\mathrm{m}^{2}$ の紫外線照射であり, 2000 時間の照射により $1836 \mathrm{MJ} / \mathrm{m}^{2}$ の紫 外線量となる。

\section{2 試験結果と考察}

図 6 に照射時間と引張せん断接着強度の関係で示す。試験体数は 5 体とし，変動係数は最大で UME シリーズが $20 \%$, ML シリーズが $5 \%$ であった。引張せん断接着強度は, 評価基準となる試験前 (0 時間)
に比べ向上し，その後は概ね安定する結果となった。照射前試験体 から引張せん断接着強度が向上した原因は，0 時間から 500 時間照 射期間中に $63^{\circ} \mathrm{C}$ の照射熱によって接着剤の硬化が進み, 接着強度が 発揮したものと推察する。また, 引張せん断接着強度のばらつきを 変動係数で評価すると, UME-G で 10\%, UME-K で $17 \%, M L-G$ で 4\%とな り，鋼材新品に比心゙経年劣化品は約 1.7 倍バラつく。一方で, 工場 成形品である CFRP 帯板 (ML) は安定した接着強度が得られていると 言える。照射時間の違いによる変動係数の変化も観察されなかった。 図 7 に 2000 時間照射後の接着面の破壊状態を示す。CF シート板と 亜鉛メッキ鋼材の接着では, 主に亜鉛メッキの剥離と, 鋼材と接着 剤の界面剥離が確認されたが, CFRP 帯板と亜鉛メッキ鋼材では, 主

表 2 CFRP の概要

\begin{tabular}{|c|c|c|}
\hline & CF シート & CFRP 帯板 \\
\hline 材種 & $\mathrm{UM} 46-40 \mathrm{G}$ & ML520 \\
\hline 厚み[mm] & 0.217 & 2.0 \\
\hline 積層数 & 6 層 & 1 枚 \\
\hline 弹性率 $[\mathrm{GPa}]$ & 440 & 285 \\
\hline 対応する2 駼片 & $\mathrm{G}-\mathrm{WC}-\mathrm{E} 0$ & $\mathrm{G}-\mathrm{WC}-\mathrm{E} 8$ \\
\hline
\end{tabular}

表 3 耐候性接着試験の試験変数

\begin{tabular}{|l|c|c|c|c|}
\hline 試験体名 & \multirow{2}{*}{ CFRP 種類 } & 鋼材種類 & 照射時間 $[\mathrm{h}]$ & 対応する \\
2 章の試験片
\end{tabular}

引張せん断接着強度 $[\mathrm{MPa}]$

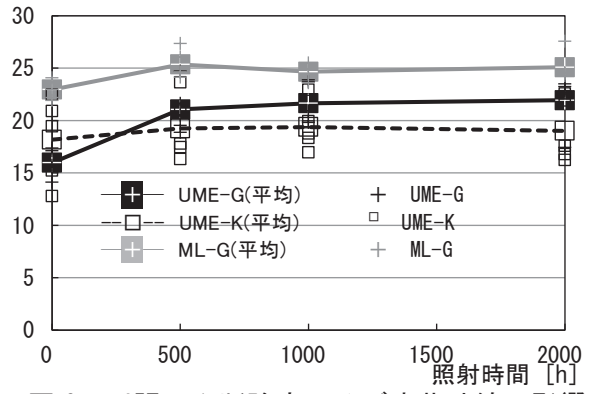

図 6 引張せん断強度に及ぼす紫外線の影響

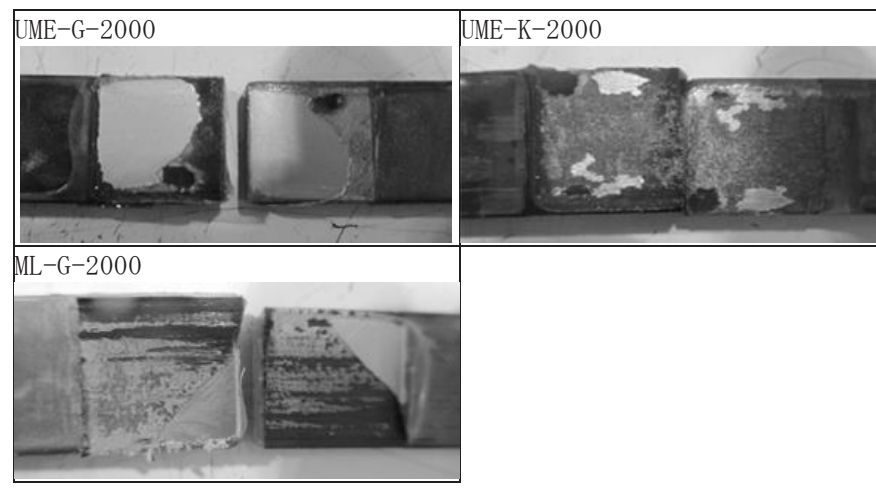

図 7 破断後の様子 
にCFRP の層内剥離と，接着剂の凝集破壊が確認された。照射時間に よって破壊状態の違いは確認されなかった。したがって，2000 時間 の耐候性試験では, 何れの試験体も曝露環境に起因寸る劣化は生じ ないと判断する。

\section{4. 温度履歴試験と引張せん断試験}

\section{1 試験体と試験方法}

本章では, 温度変化とその履歴が鋼材と CFRP との接着強度に及ぼ す影響について分析する。鋼材側の表面処理は 2 章の結果及び前章 と同様，ワイヤーカップブラシ（WC）を採用した。試験体寸法は, 図 1 に示した引張せん断接着強さ試験体と同じであり, 試験体帯板 の片方を CFRP とした。CFRP 材の概要は表 2 に示した通りである。 試験変数を表 4 に示す。試験は, 試験体を恒温恒湿槽に入れ, $60^{\circ} \mathrm{C}$ で 30 分養生後に 16 分で $-20^{\circ} \mathrm{C}$ まで下降させ, $-20^{\circ} \mathrm{C}$ で 30 分養生し, そして 16 分で $60^{\circ} \mathrm{C}$ まで戻すサイクルを 1 サイクルとし, この 1 サ イクル 92 分を 100 回繰り返した。評価として0 (試験前)，10，50， 100 サイクル毎に引張せん断接着強度を確認した。

\section{2 試験結果と考察}

温度履歴試験結果として, 図 8 に温度サイクル数と引張せん断接 着強度の関係を示す。試験体数は 6 体とし, 変動係数は最大で UME シリーズが 37\%，ML シリーズが 14\%であった。前章の耐候性試験同 様, 引張せん断接着強度は 0 サイクル（試験前）に比べ向上し, そ の後は概补安定する結果となった。引張せん断接着強度が向上した 理由は, 耐候性試験結果と同様と考える。また, 耐候性試験後の引 張せん断接着強度に比心゙, 本章の接着強度が低くなっているが，両 試験を比較すると温度履歴で用いた試験片の CF シート板厚が 0.5 〜 $1 \mathrm{~mm}$ 程度, 接着層の厚みが $0.1 \mathrm{~mm}$ 程度厚くなっており, 偏心引張の 影響であると考えられる。これにより, 各試験変数における変動係 数も前章の試験体と比較して大きい傾向にあり, UME-G で 20〜 30\%, UME-K で 11〜 13\%となっている。しかしながら, 温度サイクル回数の 違いによる変動係数の変化も観察されなかった。図 9 に 100 サイク

\section{表 4 温度履歴試験の試験変数}

\begin{tabular}{|c|c|c|c|c|}
\hline 試験体名 & CFRP 種類 & 鋼材種類 & $\begin{array}{c}\text { 温度 } \\
\text { サイクル }\end{array}$ & $\begin{array}{c}\text { 対応する } \\
2 \text { 章の試験片 }\end{array}$ \\
\hline UME-G-T0 & \multirow{4}{*}{ CF シート } & \multirow{7}{*}{$\begin{array}{l}\text { 亜鉛メッキ } \\
\text { 鋼材 SS400 }\end{array}$} & 0 & \multirow{4}{*}{ G-WC-E0 } \\
\hline UME-G-T10 & & & 10 & \\
\hline UME-G-T50 & & & 50 & \\
\hline UME-G-T100 & & & 100 & \\
\hline $\mathrm{ML}-\mathrm{G}-\mathrm{T} 0$ & \multirow{3}{*}{ CFRP 帯板 } & & 0 & \multirow{3}{*}{ G-WC-E8 } \\
\hline ML-G-T50 & & & 50 & \\
\hline ML-G-T100 & & & 100 & \\
\hline
\end{tabular}

引張せん断接着強度 $[\mathrm{MPa}]$

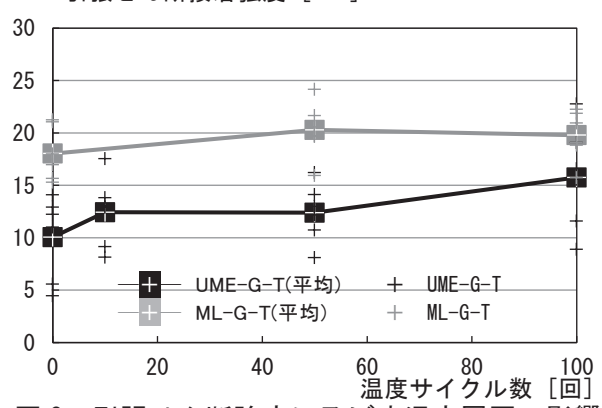

図 8 引張せん断強度に及ぼす温度履歴の影響

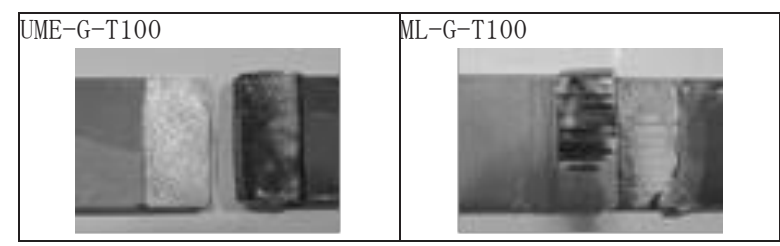

図 9 破断後の様子

ル後に試験した後の接着面の破壞状態を示す。CF シート板と亜鉛メ ッキ鋼材の接着では, 接着剂と鋼材の界面剥離であったが, CFRP 帯 板と亜鉛メッキ鋼材では, CFRP の層内剥離と, 接着剤の凝集破壊が 確認された。そして, $-20 \sim 60^{\circ} \mathrm{C}$ 間の温度サイクルによって破壊状態 の違いは確認されなかった。したがって, 何れの試験体も曝露環境 に起因する劣化は生じないと判断する。

\section{5.まとめ}

本報告では溶融亜鉛メッキ表面のメッキ層を除去することなく接 着性能を確保する CFRP 補強工法を念頭に, 各種表面処理を通した分 析を行った。その結果を以下にまとめる。

（1）接着強度は，ディスクグラインダーと亜鉛メッキを除去しな いロータリー式ブラスター・ワイヤーカップブラシに大差は 見られず，平均引張せん断強度として $11 \mathrm{MPa}$ が期待できるこ とが明らかとなった。従って, 溶融亜鉛メッキの有無が接着 強度に及ぼす影響は小さいと言える。

（2）引張せん断試験と建研式接着試験による接着強度には相関性 が見られ，上記の平均引張せん断強度を確保するためには $4 \mathrm{MPa}$ の建研式接着強度が必要であることが明らかとなった。

（3）接着面の粗さ（算術平均粗さ Ra）の差による接着強度の差は 今回採用した表面処理方法の範囲では明確に現れなかった。

（4）本報告で採用した接着工法においては, 紫外線および温度履 歴による促進曝露試験の結果, 性能低下は確認されず, また 試験結果のバラつきも曝露環境に起因する変化は無いことが 確認された。

なお，保護膜・犠牲防食作用により優れた防錆効果を発揮する覀鉛 メッキにおいて，亜鉛メッキ鋼材自体の経年変化が接着強度に及ぼ 寸影響は今後の課題であるが, 接着部は曝露環境と遮蔽されており, 着端部も接着剂の余盛・接着長の安全率が存在することから殁ど影 響はないと推測している。

\section{参考文献}

1）名取暢, 西川和廣, 村越潤, 大野崇 : 鋼橋の腐食事例調查とその分析, 土木学会論文集 No.668/1-54, pp.299-311, 2001.1

2）鋼構造シリーズ 18 腐食した鋼構造物の耐久性照查マニュアル：土木学 会, 2009

3）電気学会：電気学会技術報告 架空送電設備の鋼材腐食・摩耗現象, 2009.7

4）服部明生, 玉井宏章, 高松隆夫 : 炭素繊維プレートによる化学プラント 架構小梁補強の実施工例，日本建築学会 技術報告集 第 18 巻 第 39 号，pp. 559-564，2012.6

5）杉浦江, 小出宜央, 安森浩, 加藤健 ; 樹脂ブロック補強による隅肉溶接 継手の疲労強度向上, 第 9 回 複合・合成構造の活用に関するシンポジ ウム 講演集，土木学会・日本建築学会，2011.11

6) 米丸啓介：フェノール CFRP の長期耐久性に関する実験的研究一促進試験 と自然暴露, 日本建築学会学術講演梗概集 (東海), pp. 1481-1482, 2012.8

[2014 年 6 月 16 日原稿受理 2014 年 8 月 12 日採用決定］ 